\title{
Effect of Oxidative Stress on AhpC Activity and Virulence in katG Ser315 Thr Mycobacterium tuberculosis Mutant.
}

\author{
Ning Rintiswati ${ }^{1,2 *}$, Tri Wibawa ${ }^{2}$, Widya Asmara ${ }^{3}$, and Hardyanto Soebono ${ }^{4}$ \\ ${ }^{1}$ Doctoral Program of Health and Medical Science, Faculty of Medicine, Universitas Gadjah Mada, \\ Yogyakarta, Indonesia \\ ${ }^{2}$ Department of Microbiology, Faculty of Medicine, Universitas Gadjah Mada, Yogyakarta, Indonesia \\ ${ }^{3}$ Department of Microbiology, Faculty of Veterinary Medicine, Universitas Gadjah Mada, Yogyakarta, \\ Indonesia \\ ${ }^{4}$ Department of Dermathology and Venereology, Faculty of Medicine, Universitas Gadjah Mada, \\ Yogyakarta, Indonesia
}

\begin{abstract}
Mycobacterium tuberculosis strains resistance to INH is mainly caused by the alteration in several genes encoding the molecular targets. Mutation of kat $G$ at codon 315 especially Ser315Thr are responsible for INH resistance in a large proportion of TB cases. The aim of this study is to evaluate the influence of stress oxidative on AhpC activity of katG Ser315Thr of M.tuberculosis, and to find out the relation of AhpC and the virulence of this mutant. The study design was laboratoric experimental, subjects of study were M.tuberculosis INH resistance strains, and the treatment were serial dose of $\mathrm{H}_{2} \mathrm{O}_{2}$ Eighty five M.tuberculosis INH resistant clinical strain were screened for mutation of katGSer315Thr by PCR/RFLP and characterized on the basis of phenotypic properties (catalase activity and AhpC activity). AhpC activity of katG Ser315Thr M.tuberculosis strains in response to oxidative stress condition was evaluated by culturing the strains on liquid culture medium containing $1 \mathrm{mM} \mathrm{H}_{2} \mathrm{O}_{2}$. To ascertain role of AhpC in the virulence of katGSer315Thr mutant strains, the mutants were infected into human macrophages culture, and several indicator of virulence were observed (i.e: replication competence, and apoptosis induction on human macrophages). The results showed that katG Ser $315 \mathrm{Thr}$ were identified in $23(27,05 \%)$ of $85 \mathrm{INH}$ resistance strains, all mutant strains had decrease of catalase activity. AhpC activity of katG Ser315Thr of M.tuberculosis increased significantly with increase of hydrogen peroxide dose. In addition, it has been shown that increased AhpC activity related to replication ability of mutant, and reduction of apoptosis macrophages induction significantly. We conclude that the production of AhpC of katG Ser315Thr M.tuberculosis induced by oxidative stress. There was a role of AhpC in virulence of the M.tuberculosis kat $\mathrm{G}$ Ser315Thr strains by replication capability and macrophages apoptosis.
\end{abstract}

Keywords : katG Ser315Thr Mycobacterium tuberculosis- oxidative stress - AhpC - virulence

\section{Introduction}

Tuberculosis (TB) is a chronic infectious disease in human caused by Mycobacterium tuberculosis (M.tuberculosis) and a leading cause of death in community. The disease is still a major health problem in the world, even though ten years ago, in 1993, WHO

\footnotetext{
*Corresponding Author:

Ning Rintiswati

Department of Microbiology, Faculty of Medicine, Universitas Gadjah Mada, Yogyakarta, Indonesia, Email : rintiswati@gmail.com
}

declared TB as a global emergency (Zhang et al., 2005). The emergence of HIV and low socioeconomic status has greatly influenced the development of the disease. In most developing countries, TB is still continuing problem, because it is an endemic disease which is worsened by HIV pandemic and social changes due to ind ustrialization (Rattan et al., 1999). Another obstacle in overcoming TB problem is the emergence of M.tuberculosis mutant that is resistant to anti TB drugs. The emergence of resistant strain which is caused 
by inadequate treatment induce changes in bacterial properties which in turn become resistant to anti TB drugs. The changes include multi drug resistant (MDR), which is resistant to isoniazid and rifampicin, and extreme drug resistant (XDR) which is MDR plus resistant to one of fluoroquinolones, and one or more of injectable drugs, such as kanamicin, amikacin, capreomycin (WHO, 2009). Tuberculosis treatment began in 1944, following the discovery of streptomicin and para-aminosalisilat (PAS), and isoniazid, and other drugs (rifampicin and pirazinamid). Soon after the use of first anti TB drug, strains of resistant bacteria appeared. Previously, there was a hope that TB could be eradicated at the end of 20th century, but in fact the disease re-emerge in 1980 with increase of incidence and appearance of multi drug resistant of M.tuberculosis strain (da Silva and Ainsa, 2007).

The search for anti TB drugs has been undergoing slow moving phase. Commercially available anti TB drugs have been used for 40 years. Drug resistant M.tuberculosis strain has emerged since many years, however, until recently new and potent anti TB drug have not yet discovered. Slow development of anti TB drug is presumably caused by uncertainty in virulence and survival mechanism of M.tuberculosis. Besides, knowledge of anti TB drugs resistance mechanism is still limited. The rate of resistance is in imbalance with discovery of new drugs. The search of new and effective drugs is crucial, therefore it is necessary to study bacterial components which become target of anti TB drugs.

Several mycobacterial enzymes necessary for intracelullar survivor include catalaseperoxidase, alkyl hydroperoxide reductase, enoil$\mathrm{ACP}$ (acyl carrier protein) reductase , $\beta$-ketoasil - ACP synthetase. Synthesis of these enzymes is coded by $k a t G, a h p C$, inhA and kas $A$, respectively, in which they could be target of anti TB drug (Musser, 1995; Pym et al., 2002; Rouse et al., 1995; Costa et al., 2009).

Isoniazid (INH) is one of effective anti TB drugs in which the rate of resistance to this drug is increasing. Isoniazid is prodrug which is highly dependent on KatG to become reactive radical that attack target in M.tuberculosis cell (WHO/IUATLD, 2004; Zhang et al.,2005).

The mechanism of resistance of M.tuberculosis to INH is very complex, involving mutation on several genes, such as katG, inhA, and kasA (Rattan et al., 1999; Ozturk et al., 2005; Zhang et al., 2005). Previous studies has shown that every region has a tendency different mutation frequency in M.tuberculosis. It is suggested that this condition is caused by differences in TB control program (Bulatovic et al., 2002; Pym et al, 2002; Sajduda et al.,2004). Several reports has shown that mutation of katG is the main resistance mechanism of INH, and mutation on codon 315 (Ser315Thr) is the most frequent. This mutation has been found in more than $50-90 \%$ clinical strain, and caused increase in MIC 200 times compared to that of H37Rv M.tuberculosis. This mutation is strongly associated with MDR mutant and ability to be transmitted easily. Mutation of kat $G$ may result in decrease activity of peroxidase-catalase and deletion of this gene causes loss of activity of the enzyme(Moukrousov et al., 2002; Xueqiong et al, 2006; Hu et al., 2010 ).

KatG product has two important roles; altering INH (prodrug) into isonicotinic acid(active drug) and protect bacteria from intracellular oxidative stress (Master et al., 2001; Musser,1995; Bulatovic et al., 2002). Based on concept that peroxidase-catalase can protect bacteria from phagocytosis by macrophages, decrease or deletion of this enzyme will affect bacterial virulence. $k a t G$ mutant of M.tuberculosis should not be able to survive inside macrophages, the disease will not develop/progress and may transmission to other hosts does not occur. In fact this concept has not been the case.

Previous studies has shown that mutation on kat $G$ does not affect bacterial virulence. It is believed that M.tuberculosis has developed another mechanism to overcome 
its drawback. It is suggested that alkyl hydroperoxide reductase (AhpC) takes place of KatG for maintaining bacterial virulence. There has been a controversial evidence on the role of kat $G$ and ahpC in bacterial virulence of M.tuberculosis. In M.tuberculosis, katG deletion have an impact on $a h p C$ mutation that results in over production of this enzyme. In normal M.tuberculosis this enzyme is produced minimally (Pym et al.,2002; Hillas et al.,2000; Zhang et al., 2005). Other studies has shown that kat $G$ mutant did not influence on AhpC activity and there was no mutation on $a h p C$ (Heym et al.,1997; Guimaraes et al., 2005). Influence of AhpC on katGSer 315Thr mutant, factors effecting AhpC production and its relation with virulence of M.tuberculosis is not understood with certainty.

Recently, peroxidase-catalase and alkyl hydroperoxide reductase in INH-resistant mutant have been studied at genetic and molecular levels. Previous studies on katG showed that the role of this enzyme is not simple, involving role of AhpC (Pym et al., 2002). Both enzymes in concert may function in resistance against intracelular oxidative stress. If these enzymes prove to be the main virulence factor and intracellular resistance of M.tuberculosis, they may be the target of anti tuberculosis drugs development in the future.

This study is aimed to understand the role of AhpC, in katG mutant of INH-resistant M.tuberculosis specifically the role of AhpC in virulence of isoniazid resistant katG Ser315Thr M.tuberculosis under oxidative stress condition.

\section{Materials and Methods \\ Population and samples}

In this study 85 INH-resistant M.tuberculosis strain collected from several laboratory were used (laboratorium Rumah Sakit Persahabatan, Jakarta, Balai Pengembangan Laboratorium Kesehatan (BPLK) Bandung, Balai Besar Laboratorium Kesehatan (BBLK) Surabaya, Balai Besar Kesehatan Paru Masyarakat (BBKPM) Surakarta, Balai Kesehatan Paru Masyarakat
(BPKM) Jogjakarta, and Laboratorium Mikrobiologi Fakultas Kedokteran UGM). For control purpose, M.tuberculosis H37Rv strain was included in this study.

\section{Isolation of M.tuberculosis}

Sputum samples from TB patient were homogenized and deconcentrated with modified method of Pettrof. Sputum was added with equal volume of $4 \% \mathrm{NaOH}$ containing phenol red and flash mixed for 15-30 sec. Samples were added with phosphate buffer and spinned at $3000 \mathrm{~g}$ for mins. Supernatant was discarded, pellet was added with $\mathrm{NaOH}$ until red colour appeared. Samples were examined microscopically after Ziehl Neelsen staining and cultured on Lowenstein Jensen (LJ) medium for 3-6 weeks at $37^{\circ} \mathrm{C}$.

\section{Susceptibility tes}

Susceptibility test was done with modified indirect proportional using LJ and Middlebrook 7H10 media. Each sample was cultured on a series of LJ medium containing INH $(0.2 \mathrm{mg} / \mathrm{L}$ dan $1.0 \mathrm{mg} / \mathrm{L})$. Sample was also cultured on LJ without drug for control purpose. Inoculated media were incubated at $37^{\circ} \mathrm{C}$ for 3 weeks, and the presence of bacterial growth was examined every week. Confluent growth on control was considered as $100 \%$ growth. Sensitive or resistant determination was based on comparison between growth on medium with and without drug. An resistant isolate was determined by number of colonies on drug containing medium, if was $1 \%$ or more of number of colonies on control medium.

\section{DNA isolation}

DNA isolation was performed for INH resistant $M$. tuberculosis strain. Isolation was carried out with boiling method. Samples were scrapped from LJ and placed in tube containing $500 \mu \mathrm{L}$ of sterile aquadest and heated at $95^{\circ} \mathrm{C}$ for $5 \mathrm{~min}$. Samples were then spinned at $12.000 \times \mathrm{g}$ for $5 \mathrm{~min}$, supernatants were saved on $-20^{\circ} \mathrm{C}$ and used as DNA template. 


\section{Mutation analysis of katG Ser315Thr}

Primers for katG 315, katGIF (5'-AGCTCGTATGGCACCGGAAC) and katG 4r ( 5'-AACGGGTCCGGGAT GGTG), were used for kat $G$ fragment amplification (position 904 to 1103 in H37Rv) (Mokrousov et al., 2002).

\section{RFLP analysis codon 315}

Amplified fragments were digested with MspI. Fiveteen ul PCR product was added with $10 \mu \mathrm{L}$ of buffer and $2.7 \mu \mathrm{L}$ of the enzyme. The mixtures were placed in waterbath at $37^{\circ} \mathrm{C}$ for $8-16 \mathrm{~h}$. Digested fragments and marker $\mathrm{V}$ (Roche) were subjected to $4 \%$ agarose gel electrophoresis and results were visualized with UV light. Mutated codon 315 will be digested by MspI, resulting in 7 fragments ; 14, 6, 21, 6, 11, 10, and 132 bps. Digestion of non mutant katG Ser315Thr resulted in 6 fragments; $14,6,6,11,10$, and 153 bps (adapted from Mokrousov et al., 2002).

\section{Catalase activity assay}

Two weeks old of M.tuberculosis in LJ medium were added with mixture solution of 1:2 tween and hydrogen peroxide, incubated in room temperature for $5 \mathrm{~min}$. The height of developed bubles was measured.

\section{Exposure of M.tuberculosis to hydrogen peroxide}

M.tuberculosis was grown in $7 \mathrm{H} 9$ Midlebrook liquid medium to density was adjusted to $10^{8} \mathrm{cfu} / \mathrm{mL}$ (Mc Farland I standard), then aliquoted into $5 \mathrm{~mL}$ portions in tubes and treated with $0.02,0.2,0.1,1$ and $2 \mathrm{mMH}_{2} \mathrm{O}_{2}$ (Sigma). All tubes were incubated at $37^{\circ} \mathrm{C}$ for $4 \times 24 \mathrm{~h}$. (modified from PaganRamos et al., 2006).

\section{AhpC activity assay}

Five hundred microliters of isolate suspension was added with $500 \mathrm{ul}$ of DTT solution, incubated at room temperature for $120 \mathrm{~min}$. The rate of DTT oxidation was measured spectrophotometrically at $310 \mathrm{~nm}$ at room temperature (modified Chauhan, 2002). The experiments were repeated three times.

\section{Virulence study in human macrophage cultures}

To find out the effect of increased AhpC activity (after oxidative stress) on virulence of katG Ser315 Thr mutant, several indicator of virulence were examined, i.e: replication ability of $M$.tuberculosis after were phagocyted by human macrophage and macrophage apoptosis induction. Dose of $\mathrm{H}_{2} \mathrm{O}_{2}$ that gave the highest of AhpC activity was used in the experiment.

Macrophage preparation: macrophages were obtained from 4 blood donors. After macrophages were isolated from donors, these cells were mixed in RPMI containing fetal bovine serum. Isolated macrophages was counted with hemocytometer to get cell density of $5 \times 10^{4} / \mathrm{mL}$. Cells suspension was the divided into 24 -well plates with cover slip inside. Each well was filled with $200 \mathrm{ul}$ of macrophages suspension and incubated at $37^{\circ} \mathrm{C}$ with $5 \% \mathrm{CO}_{2}$ for $4 \times 24 \mathrm{~h}$.

Inoculation of M.tuberculosis into macrophage cultures: bacterial suspension was diluted into density of $10^{6} \mathrm{cfu} / \mathrm{mL}$, placed in a tube containing glass beads. Resuspension was done using 27-G syringe until homogenous suspension was obtained. A hundred ul of suspension was added into each wells of microplates that contained of $5 \times 10^{4} / \mathrm{mL}$ macrophage cells density, so that 1: 100 multiplicity of infection (MOI) was expected. Microplates were incubated at $37^{\circ} \mathrm{C}$ with $5 \% \mathrm{CO}_{2}$ for $2 \mathrm{~h}$. The presence of phagocytosis was confirmed with microscopic examination after auramin-acridine orange staining.

Replication ability of M.tuberculosis: after 4 X $24 \mathrm{~h}$ incubation, macrophages were lysed using lysis buffer. A hundredul of lysate was inoculated on LJ medium and incubated at $37^{\circ} \mathrm{C}$. Growth of M.tuberculosis was examined after 4 weeks, it was confirmed with Ziehl Neelsen staining. Replication 
ability was determined by comparing the number of colonies growth of strain tested with the number of colonies before infected.

Apoptosis assay: assay was done on day 4 after infection, cover slips were taken out of the well and stained with hematoxillineosin, and microscopically examined. To avoid bias, examination was performed by more than one observer and in inter observer blinded manner. Cells undergoing apoptosis will be seen as a round or oval mass, eosinophilic cytoplasm. Chromatin will be condensed and aggregated with clear border, nuclei fragmented and wrapped with cell membrane. In acute apoptosis, edge part of nuclei absorb stain strongly and there is vacuole in the middle. Cells with late phase apoptosis absorb stain weakly compared to that of cells with no apoptosis.

\section{Data analysis}

Student T-test was used for AhpC activity between oxidative stress-treated and non treated groups. Linier regression correlation test was used in analysing association between increased activity with virulence factors.

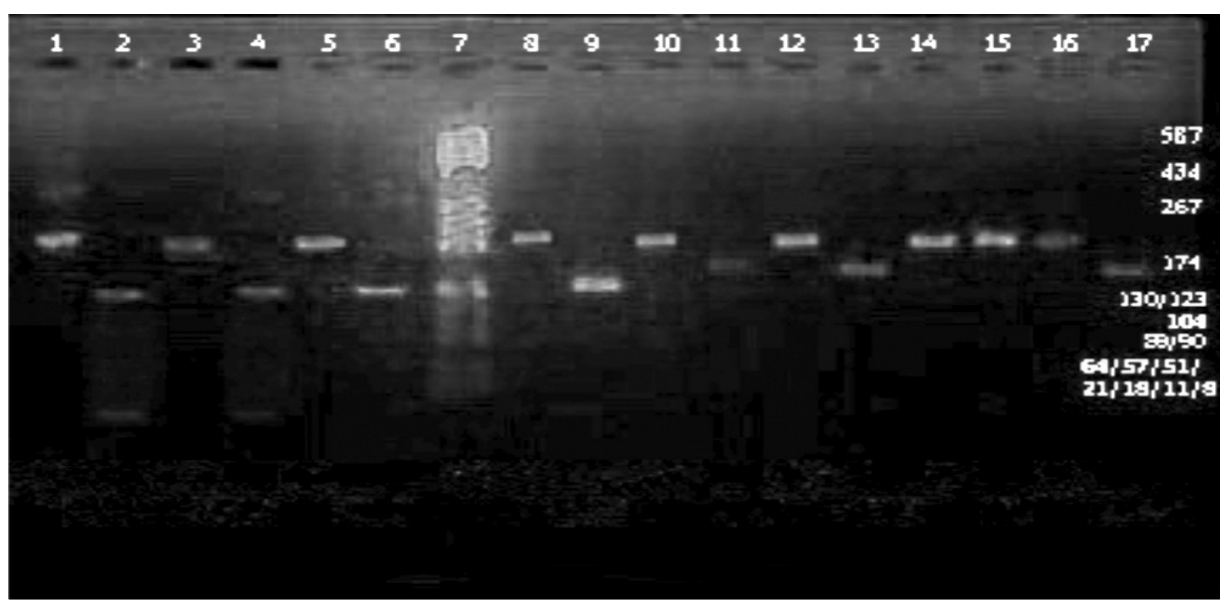

Figure1. A-lane: PCR/RFLP product of katG kodon 315. B- lane: PCR product after digested by MspI.

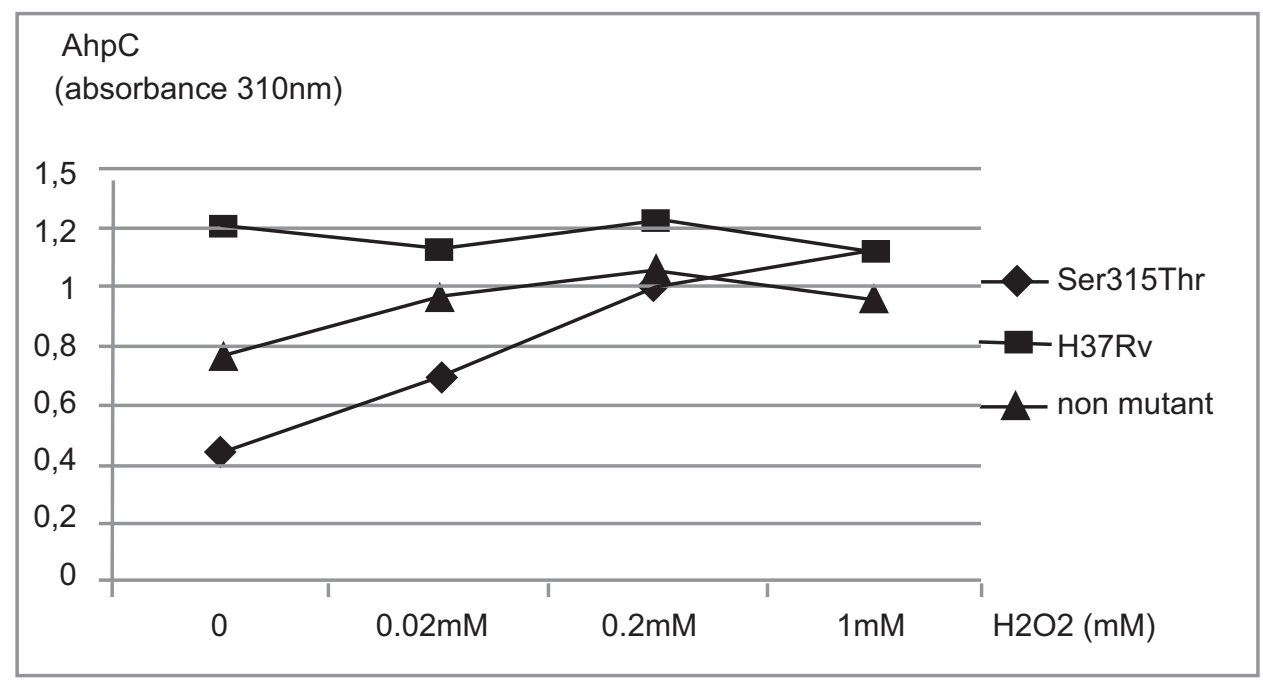

Figure 2. Mean of AhpC activity after induction with $\mathrm{H}_{2} \mathrm{O}_{2}$. 


\section{Results}

\section{Frequency of katG Ser315Thr mutant M.tuberculosis}

Mutation on katG Ser315Thr was investigated from $85 \mathrm{PCR}$ products using RFLP method. Twenty three out of 85 strain (27.05\%) were indicated as katGSer315Thr mutants. As predicted that PCR/RFLP product was $199 \mathrm{bps}$. Mutated DNA was digested into 7 fragments with the longest was $132 \mathrm{bps}$. In non mutant, product was digested into 6 fragments and the longest was 153 bps.

\section{Catalase activity in katG Ser315Thr mutant strain}

To test the catalase activity level, the semiquantitative assay was used. The H37Rv strain was included in this test to find out the basal level of AhpC. Data of Table 1 demonstrated that all of katG Ser315Thr mutant strains had height of bubbles less than $4 \mathrm{~mm}$, that indicated the catalase activity strongly decreased $(6-7 \%$ remained relative to the non mutant and H37Rv strain). In contrast, non mutant strains showed high catalase activity. The deviation standard of non mutant was 14,993, these value indicated the range variation of the catalase activities of these groups were very width, possibly due to variation of the non mutant strains.

Table 1. Mean catalase activity in strain examined

\begin{tabular}{lccl}
\hline \multicolumn{1}{c}{ Strain } & Number & $\begin{array}{c}\text { Mean bubles } \\
\text { heights }(\mathrm{mm})\end{array}$ & Significancy \\
\hline Mutant & 23 & $3,38 \pm 2,599$ & $\mathrm{p}=0,00$ \\
Non mutant & 62 & $46,06 \pm 14,993$ & $\mathrm{t}=20,963$ \\
\hline
\end{tabular}

Note : the buble height of $\mathrm{H} 37 \mathrm{Rv}$ strain is $55 \mathrm{~mm}$

\section{Effect of oxidative stress on increase AhpC activity}

In order to understand the role of AhpC as compensator of low catalase activity in katG Ser315Thr mutant, inducing expression of AhpC was examined by exposure to various concentration of $\mathrm{H}_{2} \mathrm{O}_{2}$. Then the dithiothreitol (DTT) oxidation as indicator of AhpC activity was measured by t-butil hidroperoxide decreased that observed by spectrophotometrically at absorbance 310 nm.

Inspection of AhpC level in response to $\mathrm{H}_{2} \mathrm{O}_{2}$ induction in katG Ser315 Thr of M.tuberculosis mutant strain showed increase of the $\mathrm{H}_{2} \mathrm{O}_{2}$ level have an effect on of AhpC activity, with peak induction at $1 \mathrm{mM} \mathrm{H}_{2} \mathrm{O}_{2}$. However, in non mutant of M.tuberculosis

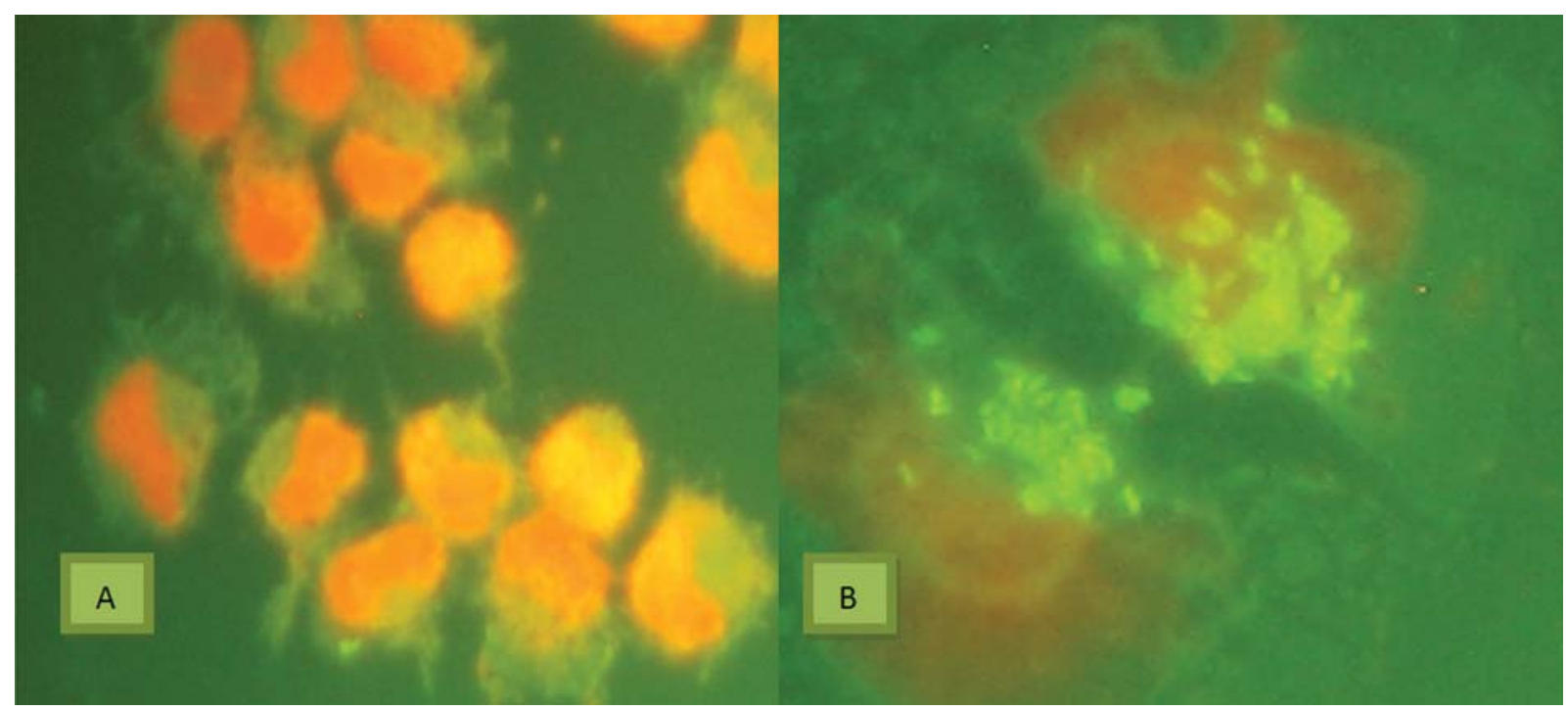

Figure 3. Macrophages phagocytosis after infected by M.tuberculosis under florescens microscope by auramineacridine orange 10xobjective. A. 4-days macrophages culture without infection. B. yellow-green appearence of mutant M.tuberculosis no 43 were phagocyted by 4-days macrophages culture by MOI 1:50, after 2 hr incubation. 
strains showed that all of the $\mathrm{H}_{2} \mathrm{O}_{2}$ levels have no effect on AhpC activity, and AhpC level in $\mathrm{H} 37 \mathrm{Rv}$ strain remained similar and were not induced by $\mathrm{H}_{2} \mathrm{O}_{2}$ (Figure 2).

Association between increase of AhpC activity and virulence of katG Ser 315Thr M.tuberculosis mutant

To reach the aim of the study in understanding association between the increased of AhpC activity and virulence of mutant we observed the several indicator, ie: ability to replicate and reducing of apoptosis macrophages induction after the mutant strain infected to peripheral blood monocytes cultures.

\section{Replication ability of mutant.}

To observe replication ability in vitro of mutant, strain were inoculated into 4 days old macrophages culture. Strain were divided into two groups; those pretreatment with oxidative stress inoculated into culture of macrophages and those without oxidative stress treatment (normal AhpC activity).

Replication ability of M.tuberculosis after phagocytized by macrophages indicate intracelullar survival capability. In this study shown in Table 2, katG Ser315Thr mutant replication before obtained stress was average
$66.88 \mathrm{cfu} / \mathrm{mL}$, but after AhpC developed (under oxidative stress), its replication ability increase twice was $144.52 \mathrm{cfu} / \mathrm{mL}$.

Table 2. Increased and replication ability in katG Ser315Thr M.tuberculosis in groups with and without oxidative stress treatment

\begin{tabular}{lll}
\hline \multicolumn{1}{c}{ Groups } & $\begin{array}{l}\text { Mean of replication } \\
\text { increased }(\mathrm{cfu} / \mathrm{mL})\end{array}$ & Significancy \\
$\begin{array}{l}\text { Without stress } \\
\text { oxidatives }\end{array}$ & $66,88 \pm 58,824$ & $\mathrm{p}=0,001$ \\
$\begin{array}{l}\text { Under stress } \\
\text { oxidatives }\end{array}$ & $141,52 \pm 118,857$ & $\mathrm{t}=3,233$ \\
\hline
\end{tabular}

These results demonstrate that the high level of AhpC affected to increase of mutant replication ability. It arisen a guess that by KatG catalase weakness compensation by AhpC development, intra cell oxidative stress effect could decrease so that bacterial replication could run optimal (see Figure 4).

\section{Macrophages apoptosis after infection with katG Ser315Thr mutant of M.tuberculosis}

Apoptosis or programmed cell death in alveolar macrophages can be induced by M.tuberculosis infection. In this study, apoptosis was observed by microscopic examination after Hematoxillin-eosin staining. Proportion of cell undergoing apoptosis per 100 macrophages cells was calculated.

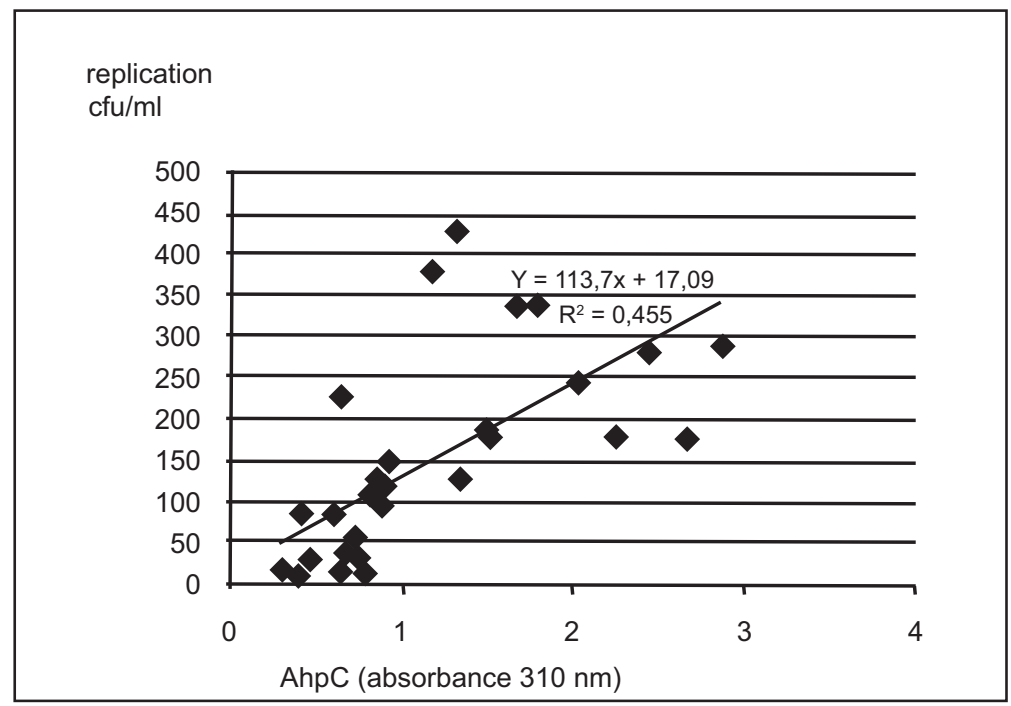

Figure 4.Correlation between increased $\mathrm{AhpC}$ and replication ability 
The results presented in this study indicate a link between increased level of AhpC and decrease of macrophage apoptosis induction, see Table 3 . The correlation between increased and macrophages apoptosis after

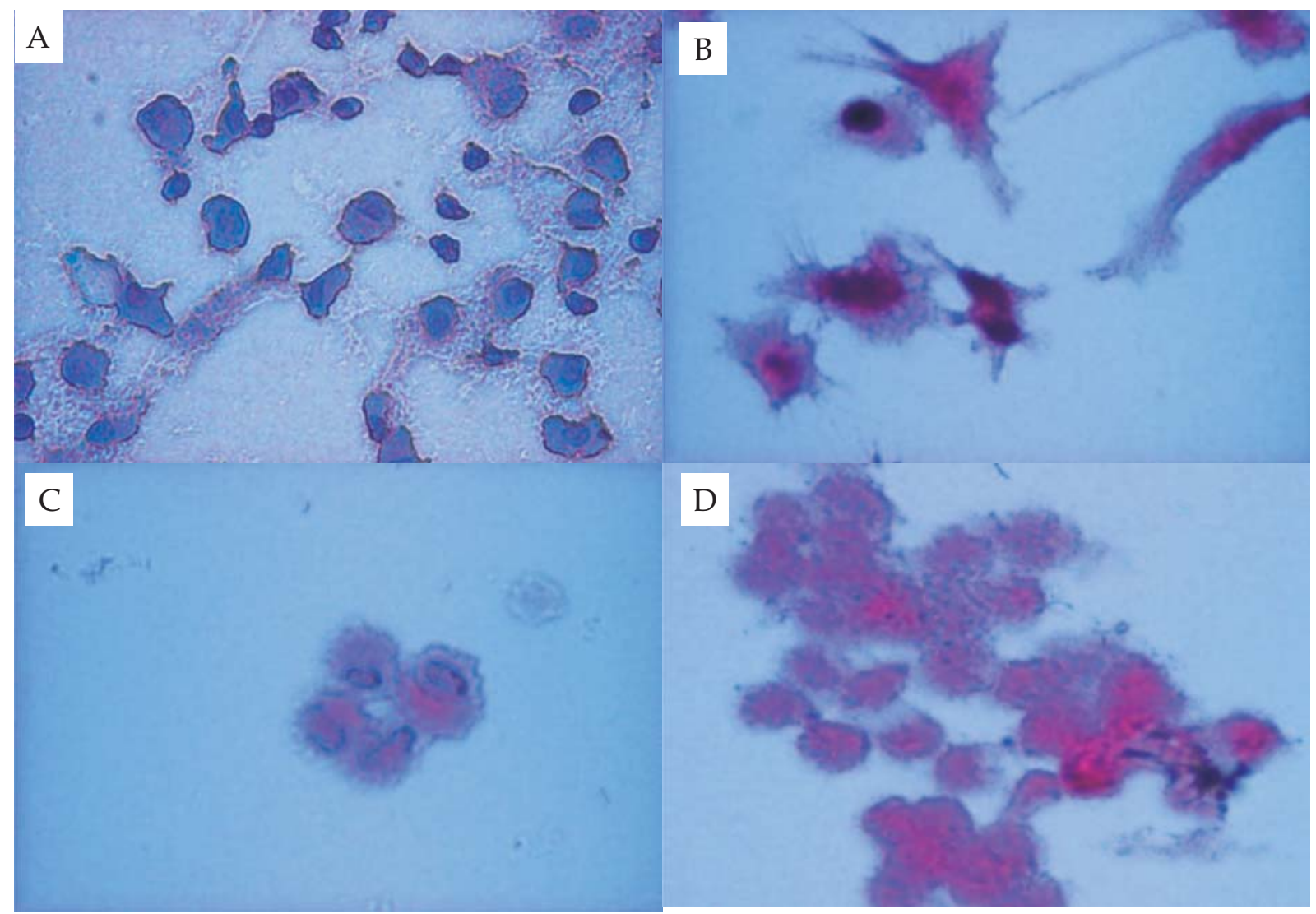

Figure 5. Appearance of macrophages by Haematoxilin-Eosine, under microscope observation ( $400 \mathrm{x}$ objective). A. 7 days macrophages culture without infection. B. macrophages culture after infected by M.tuberculosis C. Early apoptosis macrophages after infected by mutant, D. late apoptosis macrophages after infected by isolate of mutant.

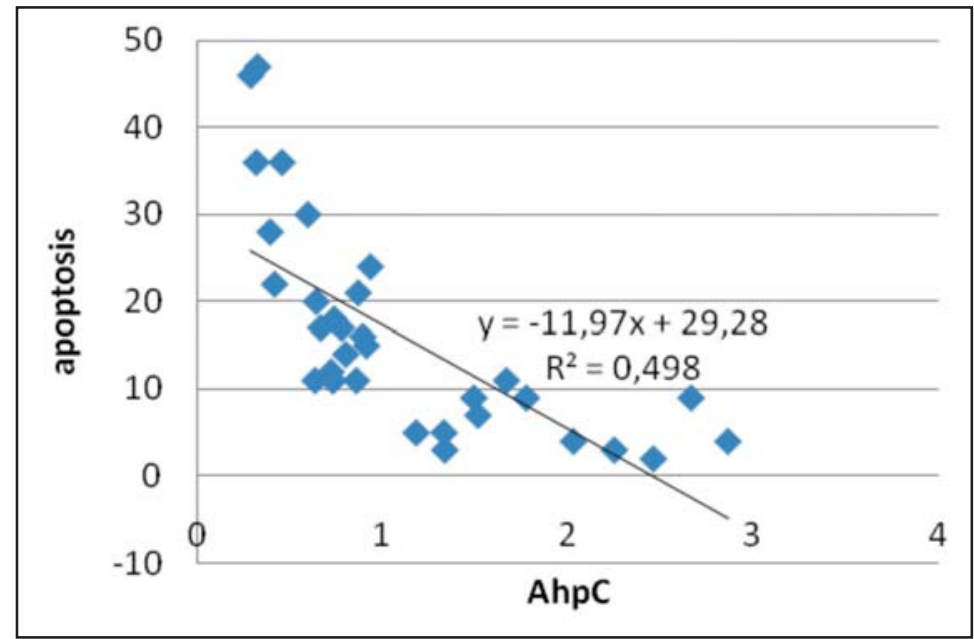

Figure 6. Correlation between increased AhpC and macrophages apoptosis induced by katG Ser315Thr M.tuberculosis mutant 
Table 3. Mean of apoptosis macrophages after infected with katG Ser315Thr M.tuberculosis mutant without oxidative stress under and oxidative stress

\begin{tabular}{lcl}
\hline $\begin{array}{c}\text { Macrophages } \\
\text { groups }\end{array}$ & $\begin{array}{c}\text { Mean of } \\
\text { apoptosis/ } \\
100 \begin{array}{c}\text { macrophage } \\
\text { cells }\end{array}\end{array}$ & significancy \\
\hline $\begin{array}{l}\text { Without } \\
\text { oxidative stress }\end{array}$ & $57,7976 \pm 11,04650$ & $\begin{array}{l}\mathrm{p}=0,00 \\
\mathrm{t}=-3,706\end{array}$ \\
$\begin{array}{l}\text { Under oxidative } \\
\text { stress }\end{array}$ & $33,0167 \pm 11,30805$ & \\
\hline
\end{tabular}

infected by katG Ser 315Thr mutant of M.tuberculosis showed by Figure 5 .

\section{Discussion}

In order to understand the role of AhpC as compensator of low catalase activity in katG Ser315Thr mutant, AhpC activity was examined with oxidative stress treatment by inducing with $\mathrm{H} 2 \mathrm{O} 2$ at different concentrations. A preliminary study was conducted by using dose of $1,2,3,5$, and $10 \mathrm{mM}$. Result showed that significant increase only occur at dose of 1 and $2 \mathrm{mM}$. At $3 \mathrm{mM}$ AhpC decreased in accordance with decreased bacterial growth. At high peroxide levels (i.e: $10 \mathrm{mM}$ ), some loss activity was detected, possibly due to increased degradation and/or inability to increase production due to excessive damage. Based on this study dose of $0.2,0.2$, and $1 \mathrm{mM}$ were used in AhpC activity assay.

The highest AhpC activity of the mutant was reached after treatment with $1 \mathrm{mM}$ of $\mathrm{H}_{2} \mathrm{O}_{2}$. In control isolate $\mathrm{H} 37 \mathrm{Rv}$ there was no significant difference in AhpC activity after treatment with different doses. This control isolate seemed to have a relatively high $\mathrm{AhpC}$ activity without $\mathrm{H}_{2} \mathrm{O}_{2}$ exposures, and the treatmen did not affect AhpC activity.

Results in this study showed that there was selectivity in AhpC regulation in M.tuberculosis. When the bacteria was under oxidative stress and KatG was decreased, compensation by AhpC occurred. It was known that during evolution process the bacteria had lost oxy $\mathrm{R}$ as ahp $\mathrm{C}$ regulator, and up to now mechanism of $a h p C$ regulation in M.tuberculosis is not yet understood. AhpC is probably induced by $\mathrm{H} 2 \mathrm{O} 2$ in the environment.

In this study virulence of the isolate was determined from ability to replicate intracellular, and apoptosis of macrophage after infected in culture of peripheral blood monocites. Oxidative stress was able to increase AhpC activity in katG Ser315Thr mutants with decreased KatG .

Ability of M.tuberculosis to manipulate macrophage is the key of its survival. This is associated with bacterial ability to avoid death inside macrophage and to induce delayed hypersensitivity. To be able to remain alive in the host, M.tuberculosis have to develop strategies; replication inside macrophage, resistance to system immune response or enable the host to control bacterial growth without destroying the bacteria. In certain condition, M.tuberculosis have to live in inactive state without loosing ability to be reactive (Glickman and Jacobs, 2001).

Data showed that mutant strain was able to replicate inside macrophage. Results also showed that significant increase of AhpC was influence the intracellular replication ability. It means that katGSer315Thr mutant can resist intracellular environment and phagocytosis by macrophage although there is a decrease of KatG, because of AhpC compensation.

Regarding the macrophages apoptosis induction by katG Ser315Thr mutant M.tuberculosis as one of virulence factor, this results indicated there was relationship of increased AhpC activity with macrophages apoptosis induction.

Based on results in this study it can be concluded that katGSer315Thr mutant M.tuberculosis is a dynamic mutant that keep balance between resistance to INH and inactivated peroxide-catalase. When peroxide-catalase is weak, this enzyme can still protect bacteria from organic peroxide produced by the host. If there is strong oxidative stress beyond peroxide-catalase strength, then compensation by AhpC occurs. Beside compensating low KatG activity, 
AhpC enhanced the replicating ability and also reduce induction of apoptosis of macrophages, so that survival of the bacteria can be maintained.

\section{Acknowledgment}

We thank Laboratorium Rumah Sakit Persahabatan Jakarta, Balai Pengembangan Laboratorium Kesehatan (BPLK) Bandung, Balai Besar Laboratorium Kesehatan (BBLK) Surabaya, Balai Besar Kesehatan Paru Masyarakat (BBKPM) Surakarta, and Balai Kesehatan Paru Masyarakat (BPKM) Jogjakarta, for providing $M$. tuberculosis isolates.

\section{References}

Bulatovic, V.M., Wangenack, N.L., Uhl, J.R., Halal,L., Roberts, G.D,Cockerill III, F.R., Rusnack,F., 2002.Oxidative stress increases susceptibility of M.tuberculosis to Isoniazid. Antimicrob. Agent Chemother. 46(9), 2765-2771.

Chauhan, R., Mande, S.C., 2002. Site-directed mutagenesis reveals a novel catalytic mechanism of $M . t b c$ alkylhydroperoxidase. Biochem. J., 367, 255-261.

Costa, E.R.D., Ribeiro, M.O., Silva, M.S.N., Ardnold, L.S., Rostirolla, D.C., Cafrune, P.I., Espinoza, R.C., Palaci, M., Telles, M.A., Ritacco, V., Suffys, N., Lopez, L., Campelo, C.L., Miranda, S.S., Kremer, K., da Silva, P.E.A., Fonseca, L.de S., Ho, J.L., Kritski, A.L., \& Rosetti, M.R.L., 2009. Correlation of mutations in katG, oxyR-ahpC and inhA genes and in vitro susceptibility in Mycobacterium tuberculosis clinical strains segregated by spoligotype families from tuberculosis prevalent countries in South America. BMC. Microbiology., 9 (39), 1-11.

da Silva, P.A., Ainsa, J.A., 2007. Drugs and Drug interaction. Dalam Palomino, J.C., Leao, S.C., Ritacco,V (eds.), Tuberculosis 2007, http://www. Tuberculosis texbook. com:593-633.

Glickman, M.S, Jacobs Jr, W.R., 2001. Microbial Pathogenesis of M.tuberculosis: dawn of a Discipline. Cell. 104, 477-485
Guimaraes, B.G., Souchon, H., Honore, N., Saint-Joanis, B., Brosch, R., Shepard, W., Cole, S.T., and Alzari, P.M., 2005. Structure and mechanism of the alkyl hydroperoxidase AhpC, a Key element of the Mycobacterium tuberculosis defense against oxidative stress. J. Biol. Chem., 280(27), 25735-25742

Heym, B., Stavropoulus, E., Honore, N., Domenech, P., Saint -Joanis, B., Wilson, T.M., Collins, D.M., Colston, M.J., Cole, S.T., 1997. Effect of overexpression of the alkyl hydroperoxide reductase AhpC on the virulence and isoniazid resisance of Mycobacterium tuberculosis. Infect. Immun. , 65(4), 1395-1401.

Hillas, P.J, de Alba, S., Oyarzbal, Wilks, A., Ortiz de Montelano, P.R., 2000. The AhpC and AhpD antioxidant defence system of M.tuberculosis. J. Biol. Chem., 275(25), 18801-18809.

Hu, Y., Hoffner, S., Jiang, W., Wang,W., Xu, B., 2010. Extensive transmission of isoniazid resistant $M$.tuberculosis and its association with increased multidrug-resistant TB in two rural counties of eastern China : A molecular epidemiological study. BMC infect. dis., 10(43), 1471-2334.

Martilla, H., Soini, H., Houvinen, P., Viljanen, M.K., 1996. katG Mutation in isoniazidresistant M.tuberculosis strain recover from Finnish patient.Anitmicrob. Agent Chemother., 40(9), 2187-2189.

Master, S.S., Springer, B., Sander, P., Boettger, E.C., Deretic, V., \& Timmins, G.S., 2002. Oxidative stress response genes in M.tuberculosis : role of ahpC in resistance to peroxynitrite and stage-specific survival in macrophages. Microbiol., 148, 3139-3144

Mokrousov, I., Otten, T., Filipenko, M., Vyazovaya, A., Chrapov, E., Limeschenko, E., Steklova, L., Vyshnevskiy, B., Narvskaya, O., 2002. Detection of isoniazid -resistant M.tuberculosis strain by a multiplex allele-specific PCR assay targeting $k a t G$ codon 315 variation. J. Clin . Microbiol., 46(5), 2509-2512 
Musser, J.M., 1995. Antimicrobial agent resistance in Mycobacteria: molecular genetic insight. Clin. Microb. Rev., 8(4), 496-514.

Ozturk, C.E., Sanic, A., Kay, D., Ceyhan, I., 2005. Molecular analysis of isoniazid, rifam pin, and streptomycin resistance in M.tuberculosis strain from patients with tuberculois in Duzie, Turkey. J. Infect Dis., 58, 309-312.

Pagan-Ramos, E., Master, S.S., Pritchett, C.L., Reimschuessel, R., Trucksis, M., Timmins, S.G., Deretic, V., 2006. Molecular and physiological effect of micobacterial oxyR inactivation. J.Bacteriol., 188 (7), 2674-2680

Pym, A.S, Saint-Joanis, B., Cole, S.T., 2002. Effect of katG mutations on the virulence of Mycobacterium tuberculosis and the implication for transmission in human. Infect. Immun., 70(9), 4955-4960.

Rattan, A., Kalia, A., Ahmad, N., 1999. Multidrug resistant Mycobacterium tuberculosis molecular respectives. Ind. J. Tub., 46, 51-63.

Rouse, D.A., Li, Z., Bai, G.H., Morris, S.L., 1995. Characterization of $k a t \mathrm{G}$ and inhA genes of isoniazid resistant Clinical Strain of M.tuberculosis. Antimicrob. Agents Chemother., 39(11), 2472-2477.

Sajduda, A., Brzostek, A., Poprawaska, M., Augustynowicz-Kope, E., Zwolska, Z., Niewmann, S., Dziadek, J., \& Hillemann, D., 2004. Molecular characterization of rifampinand isoniazid-resistant Mycobacterium tuberculosis strains isolated in Poland. J. Clin. Microbiol., 42 (6), 2425-2431.

World Health Organization/IUATLD., 2004. Anti Tuberculosis in the World. Report no.3.The WHO/IUATLD Global Project on Anti-TB drug Resistance Surveillance 1999-2002 WHO :11-12.

World Health Organization, 2009. Global Tuberculosis control, a short update to the 2009. Geneva, Switzerland, WHO/ $\mathrm{HTM} / \mathrm{TB} / 2008.394$.

Xue-qiong, W., Yang, L., Jun-xian, Z., Jianqin, L., Hong-Min, L., Guang-Yu, Z., Cui- Huan, L., Bei-Chuan, D., 2006.
Detection of mutant katG 315 \& Inh A-15 of Mycobacterium tuberculosis strain strain from Chinese patients. Clin. Med. J., 119(3), 230-233.

Zhang, Y., Vilcheze, C., Jacobs, W.R., 2005. Mechanisms of Drug Resistance in Mycobacterium tuberculosis. Dalam Cole, S.T. Tuberculosis and tubercle bacillus. ASM Press, Washington DC:115-132 